\title{
Wojciech Grabowski
}

University of Lodz

e-mail: Wojciech.Grabowski@uni.lodz.pl

\section{COMOVEMENTS OF STOCK MARKETS}

IN VISEGRAD COUNTRIES IN YEARS 2004-2017

POWIĄZANIA POMIĘDZY RYNKAMI FINANSOWYMI

W KRAJACH GRUPY WYSZEHRADZKIEJ

W LATACH 2004-2017

DOI: $10.15611 / \mathrm{pn} .2018 .519 .07$

JEL Classification: G01, G15, C32

\begin{abstract}
In this paper comovements of stock markets in the Visegrad countries in years 2004-2017 are analysed. Parameters of the VEC-GARCH-BEKK model are estimated. Results of the empirical study indicate that stock returns in Poland, the Czech Republic and Hungary were sensitive to stock returns of DAX. Moreover, investors analysed performance of stock markets in the whole group of Visegrad countries, when deciding to buy or sell stocks from one market (in Warsaw, Prague or Budapest). Results of the analysis of the shocks' transmission mechanism and the volatility transmission mechanism indicate that especially shocks coming from the German stock market strongly affected volatilities of the rates of return in the Visegrad countries.
\end{abstract}

Keywords: stock returns, comovements, VEC-GARCH-BEKK model, contagion.

Streszczenie: W artykule analizowane są powiązania pomiędzy rynkami giełdowymi krajów Grupy Wyszehradzkiej w latach 2004-2007. Szacowane są parametry modelu VEC-GARCH-BEKK. Wyniki estymacji wskazują, że stopy zwrotu dla Polski, Czech i Węgier byly wrażliwe na stopy zwrotu DAX. Ponadto inwestorzy analizowali zmiany stóp zwrotu w całej Grupie Wyszehradzkiej i podejmowali decyzje inwestycyjne na jednej z giełd (warszawskiej, praskiej czy w Budapeszcie). Wyniki analizy mechanizmu transmisji szoków i zmienności wskazują, że kraje Grupy Wyszehradzkiej były szczególnie wrażliwe na szoki pochodzące $z$ Niemiec.

Slowa kluczowe: stopy zwrotu, transmisja szoków, VEC-GARCH-BEKK, efekt zarażania.

\section{Introduction}

International stock market correlations have attracted much attention with the integration and globalization of financial markets. The correlation structure of equity returns is an important component of asset allocation decisions. Since 
correlations change through time, their dynamic cross-country examination provides clues as to why they change.

At the early stages of transition, the CEE-3 (Central and Eastern European countries: Poland, the Czech Republic and Hungary) stock markets were relatively poorly integrated with the stock markets in developed economies and international investors included assets from post-communist economies in their portfolios in order to reduce the investment risk (see e.g. [Gilmore et al. 2005]). The accession of the countries under consideration to the European Union on May 1, 2004 attracted the interest of many investors who had earlier refrained from investing in these countries because of political, corporate governance and liquidity risks [Syllignakis, Kouretas 2011]. Growing integration of stock markets in the CEE-3 countries with developed ones was documented among others by Syllignakis and Kouretas [2011] as well as by Syriopoulos [2007]. With a higher level of integration, the benefits from using the portfolio diversification strategy became smaller [Brzeszczyński, Welfe 2007].

In this paper we study the phenomenon of comovements of stock returns in Visegrad countries in years 2004-2017. Period under consideration encompasses precrisis period, the subprime crisis period, the period of the euro area sovereign debt crisis and the post-crisis period. We estimate parameters of the asymmetric VEC-GARCH-BEKK model. Thanks to using this approach, we analyse not only the linkages between the rates of return, but we study the shocks' and the volatility transmission mechanism as well. Moreover, we test whether the impact of positive and negative shocks was symmetric, imposing restrictions on consecutive parameters of the asymmetric VEC-GARCH-BEKK model.

This paper has the following structure. In the second section a description of a phenomenon of contagion and spillover among stock markets is provided. In the third section performance of stock markets in Visegrad countries after the EU accession is analysed. Methodology is presented in the fourth section and the results of the empirical investigation are presented in section five. Sixth section provides conclusions.

\section{Contagion and spillover among the stock markets}

The issue of contagion and risk spillover among stock markets was especially important during the subprime mortgage crisis of 2007-2009 and during the Euro Area sovereign debt crisis in 2010-2013. The stock markets in the CEE-3 countries were hit dramatically by negative tendencies in the global financial markets. As a result of the global financial crisis of 2007-2013, institutional investors withdrew almost all their investments from the emerging markets. Facing bankruptcy, those institutional investors moved to liquidate most of their stocks, bonds and currencies from the CEE-3 and other emerging markets and invested instead in safer assets such as US government bonds or German bonds. As a result, the stock markets in 
Poland, the Czech Republic and Hungary went under substantial pressure because of the massive capital flight.

The creation of liabilities that were denominated in foreign currency was a part of the problem during the subprime crisis. Though some emerging economies understood the negative effects that currency mismatches could create after the crises of 1994-2002, several countries in the Central and Eastern Europe borrowed in foreign currency during the subsequent cycle. This mistake was made by Hungary and by Poland - to a lesser extent. These transactions were interpreted as a failed "convergence play" among the countries of the Central and Eastern Europe that were on the path to joining the Euro. This resulted in the episode of the carry trade observed in foreign exchange and money markets in the CEE-3 countries.

The impact of the subprime mortgage crisis on the comovements among rates of return of stock indices in Poland, the Czech Republic and Hungary as well as linkages among these markets and developed stock markets in the crisis period were broadly discussed in the economic literature (see e.g. [Syllignakis, Kouretas 2011]; [Horvath, Petrovski 2013]). The interlinkages between stock markets in post-communist economies and developed ones during the Euro Area sovereign debt crisis were studied among others by Bieńkowski, Gawrońska-Nowak and Grabowski [2014].

\section{Performance of the stock markets in Visegrad countries in years 2004-2017}

On the $1^{\text {st }}$ of May 2004 Poland, Czech Republic, Hungary and other countries in the Central and Eastern Europe joined the European Union. Since then, different phases of the stock markets' performance have been noticed. After long-term of growth of stock indices all around the world, global financial crisis started in August 2007. A considerable downturn in the value of investment portfolios was noticed and the loss of confidence in the market triggered a credit crunch and shortage of liquidity. Next, after short recovery, the euro area sovereign debt crisis started and after the announcement of the OMT programme by the president of the European Central Bank Mario Draghi, a recovery in financial markets (especially bond markets) was noticed, since the trust in Euro convertibility increased substantially (see e.g. [Falagiarda, Reitz 2015]; [Grabowski, Stawasz 2013, 2017]; [Kilponen et al. 2015]).

According to the periodization of the global financial crisis [Winkler 2015], in the period April 2004 - June 2017 five phases can be distinguished:

- period before the global financial crisis (2004-04-01 - 2007-08-08);

- period of financial turmoil (2007-08-09 - 2008-09-12), which started on the August 9, 2007 when the BNP Paribas bank announced that it suspended payments from three funds investing on the market of bonds secured by mortgages of increased risk; 
- period of the subprime crisis (2008-09-15 - 2009-10-09), which starts with the bankruptcy of the Lehman Brothers investment bank;

- period of the euro area sovereign debt crisis after sovereign ratings in Greece were downgraded, before the OMT programme was announced (2009-10-10 2012-07-26);

- post-crisis period after the announcement of the OMT programme by the European Central Bank (2012-07-27 - 2017-12-31).

Results of the analysis presented in Table 1 indicate that before the global financial crisis started, positive rates of return were noticed on all 4 markets. However, stock indices of the CEE-3 countries (especially WIG and BUX) grew faster than $\mathrm{DAX}^{1}$. However, risk associated with investing in equities of Visegrad countries (measured by sample standard deviation) turned out to be higher than the risk associated with investing in German equities.

In the first phase of the global financial crisis (second subperiod) stock markets of the CEE-3 countries dwindled faster than the German stock market. After the Lehman Brothers bankruptcy and before the euro area sovereign debt crisis started, stock markets in Budapest and Warsaw performed relatively better than the German and Czech stock market. Positive average rates of return were observed in the case of Poland and Hungary, while average rates of return for DAX and PX were negative.

Table 1. Descriptive statistics for the rates of return

\begin{tabular}{|c|c|c|c|c|c|c|c|c|c|c|}
\hline Index & \multicolumn{2}{|c|}{ Sub. 1} & \multicolumn{2}{|c|}{ Subperiod 2} & \multicolumn{2}{|c|}{ Subperiod 3} & \multicolumn{2}{|c|}{ Subperiod 4} & \multicolumn{2}{|c|}{ Subperiod 5} \\
\hline DAX & Mean & 0.0008 & Mean & -0.0007 & Mean & -0.0002 & Mean & 0.0002 & Mean & 0.0005 \\
\hline & $\begin{array}{l}\text { Standard } \\
\text { Deviation }\end{array}$ & 0.009 & $\begin{array}{l}\text { Standard } \\
\text { Deviation }\end{array}$ & 0.013 & $\begin{array}{l}\text { Standard } \\
\text { Deviation }\end{array}$ & 0.024 & $\begin{array}{l}\text { Standard } \\
\text { Deviation }\end{array}$ & 0.015 & $\begin{array}{l}\text { Standard } \\
\text { Deviation }\end{array}$ & 0.012 \\
\hline & Skewness & -0.371 & Skewness & -0.515 & Skewness & 0.374 & Skewness & -0.201 & Skewness & -0.354 \\
\hline & Kurtosis & 3.725 & Kurtosis & 7.537 & Kurtosis & 6.437 & Kurtosis & 5.039 & Kurtosis & 5.018 \\
\hline \multirow[t]{4}{*}{ WIG } & Mean & 0.0011 & Mean & -0.0016 & Mean & 0.00006 & Mean & -0.00003 & Mean & 0.0003 \\
\hline & $\begin{array}{l}\text { Standard } \\
\text { Deviation }\end{array}$ & 0.011 & $\begin{array}{l}\text { Standard } \\
\text { Deviation }\end{array}$ & 0.015 & $\begin{array}{l}\text { Standard } \\
\text { Deviation }\end{array}$ & 0.022 & $\begin{array}{l}\text { Standard } \\
\text { Deviation }\end{array}$ & 0.012 & $\begin{array}{l}\text { Standard } \\
\text { Deviation }\end{array}$ & 0.009 \\
\hline & Skewness & -0.521 & Skewness & -0.160 & Skewness & -0.283 & Skewness & -0.632 & Skewness & -0.684 \\
\hline & Kurtosis & 4.931 & Kurtosis & 4.414 & Kurtosis & 4.092 & Kurtosis & 6.556 & Kurtosis & 6.877 \\
\hline \multirow[t]{4}{*}{ PX } & Mean & \begin{tabular}{|l|}
0.0009 \\
\end{tabular} & Mean & -0.0012 & Mean & -0.0004 & Mean & -0.0004 & Mean & 0.00004 \\
\hline & $\begin{array}{l}\text { Standard } \\
\text { Deviation }\end{array}$ & 0.011 & $\begin{array}{l}\text { Standard } \\
\text { Deviation }\end{array}$ & 0.015 & $\begin{array}{l}\text { Standard } \\
\text { Deviation }\end{array}$ & 0.030 & $\begin{array}{l}\text { Standard } \\
\text { Deviation }\end{array}$ & 0.013 & $\begin{array}{l}\text { Standard } \\
\text { Deviation }\end{array}$ & 0.009 \\
\hline & Skewness & -0.548 & Skewness & 0.158 & Skewness & -0.423 & Skewness & -0.274 & Skewness & -0.368 \\
\hline & Kurtosis & 8.083 & Kurtosis & 6.313 & Kurtosis & 8.451 & Kurtosis & 6.180 & Kurtosis & 5.022 \\
\hline \multirow[t]{4}{*}{ BUX } & Mean & \begin{tabular}{|l|}
0.0011 \\
\end{tabular} & Mean & -0.0014 & Mean & 0.0002 & Mean & -0.0003 & Mean & 0.0006 \\
\hline & \begin{tabular}{|l} 
Standard \\
Deviation
\end{tabular} & 0.014 & $\begin{array}{l}\text { Standard } \\
\text { Deviation }\end{array}$ & 0.016 & $\begin{array}{l}\text { Standard } \\
\text { Deviation }\end{array}$ & 0.033 & $\begin{array}{l}\text { Standard } \\
\text { Deviation }\end{array}$ & 0.017 & $\begin{array}{l}\text { Standard } \\
\text { Deviation }\end{array}$ & 0.011 \\
\hline & Skewness & -0.613 & Skewness & 0.189 & Skewness & -0.642 & Skewness & -0.557 & Skewness & -0.304 \\
\hline & Kurtosis & 5.496 & Kurtosis & 3.796 & Kurtosis & 6.438 & Kurtosis & 4.885 & Kurtosis & 5.339 \\
\hline
\end{tabular}

Source: own study.

${ }^{1}$ Variants with stock indexes of alternative stock markets (CAC40, Eurostoxx50, NIKKEI, lagged S\&P500) were considered as well. Results concerning impact of these stock returns and the correlations among shocks turned out to be similar. These results are available upon request. 
Risk associated with investing in equities was the highest in the third subperiod. Sample standard deviations for the third subperiod were higher than doubled standard deviations for the first sub period. During the euro area sovereign debt crisis average positive rate of return was observed in the case of DAX. Investors got rid of treasury bonds of peripheral euro area countries and demand for German bunds increased significantly.

Table 2. Results of testing of order of integration for the logarithms of stock prices

\begin{tabular}{|l|c|c|c|c|}
\hline Index & $\begin{array}{c}\text { ADF-GLS } \\
\text { statistic for } \\
\text { logarithms } \\
\text { of price }\end{array}$ & $\begin{array}{c}\text { Critical value } \\
\text { for the } 0.05 \text { level } \\
\text { of significance }\end{array}$ & $\begin{array}{c}\text { ADF-GLS } \\
\text { statistic for rates } \\
\text { of return }\end{array}$ & $\begin{array}{c}\text { Critical value } \\
\text { for the } 0.05 \text { level } \\
\text { of significance }\end{array}$ \\
\hline DAX & -2.253 & -2.843 & -7.733 & -2.833 \\
\hline WIG & -1.521 & -2.834 & -4.825 & -2.841 \\
\hline PX & -1.015 & -2.843 & -6.123 & -2.838 \\
\hline BUX & -1.229 & -2.843 & -7.882 & -2.838 \\
\hline
\end{tabular}

Source: own study.

Table 2 presents the results of testing of orders of integration for logarithms of stock prices and logarithmic rates of return using ADF-GLS test [Elliot et al. 1996]. Results indicate that all prices are integrated of order 1. Therefore, in order to analyse comovements among stock markets in Visegrad countries, we can estimate parameters if the VEC(S)-GARCH-BEKK model. Utilizing this approach allows identifying long-run relations among stock prices and short-run relations among the rates of return.

\section{Methodology}

In order to analyse the comovements among stock markets in Visegrad countries, as well as the impact of the rates of return in Germany (leading stock market in the European Union) on the performance of stock markets in CEE-3 countries, we propose the estimation of the parameters of the following VEC(S)-GARCH$-\mathrm{BEKK}^{2}$ :

$$
\begin{gathered}
\Delta \mathbf{p}_{t}=\mathbf{A} \mathbf{B}^{T} \mathbf{p}_{t-1}+\sum_{i=1}^{S-1} \boldsymbol{\Gamma}_{i} \Delta \mathbf{p}_{t-i}+\boldsymbol{\varepsilon}_{t}, \quad E\left(\boldsymbol{\varepsilon}_{t} \boldsymbol{\varepsilon}_{t}^{T}\right)=\mathbf{H}_{t}, \\
\mathbf{H}_{t}=\mathbf{C} \mathbf{C}^{T}+\mathbf{G} \boldsymbol{\varepsilon}_{t-1} \boldsymbol{\varepsilon}_{t-1}^{T} \mathbf{G}^{T}+\mathbf{Q} \mathbf{H}_{t-1} \mathbf{Q}^{T}+\mathbf{D} \boldsymbol{\zeta}_{t-1} \zeta_{t-1}^{T} \mathbf{D}^{T},
\end{gathered}
$$

${ }^{2}$ BEKK specification for residuals is very flexible. Apart from this specification, DCC and VCC specifications were considered. Results for correlation coefficients among shocks turned out to be very similar. They are available upon request. 
where $\mathbf{p}_{t}=\left[\begin{array}{llll}p_{t}^{D E} & p_{t}^{P L} & p_{t}^{C Z} & p_{t}^{H U}\end{array}\right]^{T}$, the elements of this vector denote logarithms of stock prices respectively for Germany, Poland, Czech Republic and Hungary, $\mathbf{B}$ and $\mathbf{A}$ denote matrix of cointegrating vectors and matrix of weights respectively, $\boldsymbol{\Gamma}_{1}, \boldsymbol{\Gamma}_{2}, \ldots$ measure the impact of the lagged rates of return on actual ones, $\boldsymbol{\varepsilon}_{t}$ is the vector of shocks coming from different markets. The $k$-th element of the vector $\zeta_{t}$ is defined as follows:

$$
\zeta_{k t}=\varepsilon_{k t} I\left\{\varepsilon_{k t}<0\right\} .
$$

Matrix $\mathbf{H}_{t}$ consists of variances of shocks and covariances among them. Elements of matrix $\mathbf{G}$ measure the impact of the lagged shocks on variances and covariances, while the elements of matrix $\mathbf{Q}$ measure the impact of the lagged covariances on current ones. Elements of matrix $\mathbf{C}$ can be interpreted as the constant parts of variances and covariances. Next, time-varying correlations should be calculated in the following way:

$$
\hat{\rho}_{t}^{i j}=\frac{\hat{h}_{t}^{i j}}{\sqrt{\hat{h}_{t}^{i i} \hat{h}_{t}^{j j}}},
$$

where $\hat{h}_{t}^{i j}$ denotes the element of the $i$-th row and $j$-th column of the matrix $\mathbf{H}_{t}$.

\section{Results and discussion}

In the first step, the cointegration rank should be identified. Results of testing the cointegration rank are presented in Table 3.

Table 3. Results of testing the cointegration rank

\begin{tabular}{|c|c|c|}
\hline Rank & Trace statistic & 5\% critical value \\
\hline 0 & 47.572 & 47.21 \\
\hline 1 & 17.24 & 29.68 \\
\hline 2 & 5.92 & 15.41 \\
\hline 3 & 0.00 & 3.76 \\
\hline
\end{tabular}

Source: own study.

Next, the cointegrating relation is identified and parameters of the VEC-GARCH-BEKK model are estimated. Table 4 presents the results of the estimation of the parameters of the VECM for logarithms of prices and the rates of return, while Table 5 presents the results for the equations of variances and covariances among shocks. 
Table 4. Results of the estimation of the asymmetric VEC-GARCH-BEKK model parameters. Equation of prices and rates of return

\begin{tabular}{|c|c|c|c|c|}
\hline & $r_{t}^{D E}$ & $r_{t}^{P L}$ & $r_{t}^{C Z}$ & $r_{t}^{H U}$ \\
\hline$c e_{t-1}$ & $0.0012^{* *}$ & $0.0012^{* * *}$ & $0.0014 * *$ & $-0.0005^{*}$ \\
\hline$r_{t-1}^{D E}$ & 0.0164 & $0.092^{* * *}$ & $0.177^{* * *}$ & $0.093^{* * *}$ \\
\hline$r_{t-1}^{P L}$ & 0.0531 & $0.083^{* * *}$ & 0.039 & $0.074 * *$ \\
\hline$r_{t-1}^{C Z}$ & $-0.1124 * * *$ & $-0.097 * * *$ & $-0.133^{* * *}$ & $-0.131 * *$ \\
\hline$r_{t-1}^{H U}$ & 0.0119 & -0.009 & $0.056^{* * *}$ & 0.011 \\
\hline Cointegrating equation & \multicolumn{4}{|c|}{$c e_{t}=p_{t}^{P L}+4.74-2.58 p_{t}^{C Z}+2.67\left(p_{t}^{H U}-p_{t}^{G E}\right)$} \\
\hline
\end{tabular}

Source: own study.

Table 5. Results of the estimation of the parameters of the asymmetric VEC-GARCH-BEKK. Equations of variances and covariances among shocks (Multivariate $t$-student distribution of error terms)

\begin{tabular}{|l|c|c|c|c|c|}
\hline & & $\begin{array}{c}\text { Germany } \\
(i=1)\end{array}$ & $\begin{array}{c}\text { Poland } \\
(i=2)\end{array}$ & $\begin{array}{c}\text { The Czech } \\
\text { Republic } \\
(i=3)\end{array}$ & $\begin{array}{c}\text { Hungary } \\
(i=4)\end{array}$ \\
\hline \multirow{5}{*}{ Matrix C } & $\mathrm{C}(\mathrm{i}, 1)$ & 0.0015 & 0.0001 & -0.0001 & 0.0013 \\
\cline { 2 - 6 } & $\mathrm{C}(\mathrm{i}, 2)$ & - & 0.0003 & -0.0017 & -0.0008 \\
\cline { 2 - 6 } & $\mathrm{C}(\mathrm{i}, 3)$ & - & - & 0.0011 & -0.0013 \\
\cline { 2 - 6 } & $\mathrm{C}(\mathrm{i}, 4)$ & - & - & - & -0.0000 \\
\hline \multirow{5}{*}{ Matrix A } & $\mathrm{A}(\mathrm{i}, 1)$ & $0.063^{* *}$ & -0.027 & 0.010 & $0.058^{* * *}$ \\
\cline { 2 - 6 } & $\mathrm{A}(\mathrm{i}, 2)$ & -0.015 & $0.108^{* * *}$ & 0.035 & $0.055^{* * *}$ \\
\cline { 2 - 6 } & $\mathrm{A}(\mathrm{i}, 3)$ & $0.040^{*}$ & $-0.051^{*}$ & $0.026^{* * *}$ & $0.068^{* * *}$ \\
\cline { 2 - 6 } & $\mathrm{A}(\mathrm{i}, 4)$ & -0.005 & -0.015 & -0.044 & $0.227^{* * *}$ \\
\cline { 2 - 6 } & $\mathrm{B}(\mathrm{i}, 1)$ & $0.955^{* * *}$ & $0.019^{* *}$ & 0.016 & $-0.027^{* * *}$ \\
\cline { 2 - 6 } & $\mathrm{B}(\mathrm{i}, 2)$ & -0.008 & $0.996^{* * *}$ & -0.014 & $-0.009^{*}$ \\
\cline { 2 - 6 } & $\mathrm{B}(\mathrm{i}, 3)$ & -0.002 & $0.023^{* *}$ & $0.894^{* * *}$ & 0.015 \\
\cline { 2 - 6 } & $\mathrm{B}(\mathrm{i}, 4)$ & -0.013 & $0.029^{* * *}$ & -0.013 & $0.951^{* * *}$ \\
\hline \multirow{5}{*}{ Matrix D } & $\mathrm{D}(\mathrm{i}, 1)$ & $0.292^{* * *}$ & $0.103^{* * *}$ & $0.051^{*}$ & $0.126^{* * *}$ \\
\cline { 2 - 6 } & $\mathrm{D}(\mathrm{i}, 2)$ & $0.083^{* * *}$ & $0.105^{* *}$ & 0.024 & -0.029 \\
\cline { 2 - 6 } & $\mathrm{D}(\mathrm{i}, 3)$ & $0.111^{* * *}$ & $0.163^{* * *}$ & $0.144^{* * *}$ & $-0.203^{* *}$ \\
\cline { 2 - 6 } & $\mathrm{D}(\mathrm{i}, 4)$ & 0.036 & 0.021 & $0.213^{* * *}$ & 0.044 \\
\hline
\end{tabular}

Source: own study.

In order to check, whether the specification was appropriate, different diagnostic tests were conducted. Results of these diagnostic tests are presented in Table 6 . These results indicate that using the asymmetric GARCH-BEKK model, as well as the choice of the distribution of error terms, were justified. Moreover, there was no problem of autocorrelation and error terms were homoscedastic. 
Table 6. Results of diagnostic tests

\begin{tabular}{|l|c|c|}
\hline \multicolumn{1}{|c|}{ Kind of test } & Value of statistic & p-value \\
\hline Asymmetry in GARCH-BEKK model & 23.914 & 0.000 \\
\hline $\begin{array}{l}\text { Multivariate t-student distribution of error term in GARCH- } \\
\text { BEKK model }\end{array}$ & 5.211 & 0.266 \\
\hline Validity of restrictions & 2.371 & 0.124 \\
\hline Autocorrelation for GARCH-adjusted residuals & 15.257 & 0.506 \\
\hline Homoscedasticity for GARCH-adjusted residuals $\left(r_{t}^{D E}\right)$ & 2.683 & 0.612 \\
\hline Homoscedasticity for GARCH-adjusted residuals $\left(r_{t}^{P L}\right)$ & 3.978 & 0.409 \\
\hline Homoscedasticity for GARCH-adjusted residuals $\left(r_{t}^{C Z}\right)$ & 2.183 & 0.702 \\
\hline Homoscedasticity for GARCH-adjusted residuals $\left(r_{t}^{H U}\right)$ & 1.984 & 0.739 \\
\hline
\end{tabular}

${ }^{*}$ Breusch-Pagan-Godfrey test was used.

Source: own study.

According to the results of the estimation, value of the index on the Polish stock exchange is positively affected by the value of the index of the Prague stock exchange and negatively by the difference between BUX and DAX in the long-run. Error correction mechanism was identified in the German, Czech and Hungarian stock market. In the case of the Polish stock market some signs of inefficiency were identified. After positive (negative) rate of return on the Polish stock market at a day $t-1$, probability of a positive (negative) rate of return at a day $t$ was large. This result indicates that though the rates of return are stationary, they may be persistent especially during the crisis. Similar phenomenon was observed for the Polish currency market by Grabowski and Welfe [2016].

Rates of return in the German stock market strongly affected the rates of return in the Polish, Hungarian and Czech stock market. In the case of stock markets in transition countries, some results indicate that many investors rebalanced their portfolio short after observing negative (positive) rates of return. For example, negative estimate of the parameter for the variable $r_{t-1}^{C Z}$ in the equation explaining $r_{t}^{D E}$ indicates that after observing a negative rate of return on the Prague stock market, investors might have pulled out of the Czech stock market and invest in the German one.

Statistical significance of many parameters from the $\mathbf{A}$ and $\mathbf{D}$ matrix indicate that the shocks' spillover was observed in the period under consideration and shocks coming from specific stock markets affected variances and covariances between the shocks. High (in absolute value) and significant parameters in the $1^{\text {st }}$ row of the $\mathbf{D}$ matrix indicate that the negative shocks coming from Germany greatly affected variances and covariances. However, the impact of shocks coming from Poland, Hungary and the Czech Republic turned out to be significant as well. In general, 
absolute values of estimates of the sum of matrices $\hat{\mathbf{A}}+\hat{\mathbf{D}}$ are higher than the absolute values of the estimates of matrix $\hat{\mathbf{A}}$. This means that the negative shocks have stronger impact on the elements of the covariance matrix than the positive shocks. The asymmetric effects of positive and negative shocks are in line with multiple findings in the literature (see e.g. [Bieńkowski et al. 2014]). According to Albuqurque and Vega [2009] asymmetric impact of shocks may be due to information asymmetry and the presence of agents with superior knowledge.

In order to compare the performance of the correlations among the shocks in five sub-periods, the average values of measure (2) were calculated. Table 7 presents the average estimates of the correlation coefficients.

Table 7. Average values of correlation coefficients among the shocks in five sub-periods

\begin{tabular}{|c|c|c|c|c|c|}
\hline Pair & 1 & 2 & 3 & 4 & 5 \\
\hline DAX-WIG & 0.52 & 0.64 & 0.67 & 0.63 & 0.51 \\
\hline DAX-BUX & 0.13 & 0.12 & 0.24 & 0.17 & 0.13 \\
\hline DAX-PX & 0.50 & 0.61 & 0.64 & 0.58 & 0.50 \\
\hline WIG-BUX & 0.18 & 0.23 & 0.28 & 0.17 & 0.13 \\
\hline WIG-PX & 0.53 & 0.67 & 0.75 & 0.60 & 0.48 \\
\hline BUX-PX & 0.19 & 0.23 & 0.38 & 0.23 & 0.12 \\
\hline
\end{tabular}

Source: own study.

The results indicate that at the beginning of the global financial crisis the sharp increases of correlations among shocks were recorded. In the period of the euro area sovereign debt crisis the stock markets in Visegrad countries were sensitive to global shocks; however, the level of sensitivity was a bit lower than during the banking crisis in the US. It turned out that after the introduction of the OMT programme, the sensitivity of the stock market returns in Visegrad countries to external shocks became weaker not only in comparison with the crisis period, but in comparison with the pre-crisis period as well.

\section{Conclusions}

In this paper, the comovements of stock markets in Visegrad countries after the EU accession were studied. Parameters of the asymmetric VEC-GARCH-BEKK model were estimated and time-varying correlation coefficients and volatilities were calculated.

Results of the estimation indicate that stock markets in Visegrad countries were sensitive to the rates of return on DAX. It means that the performance of the global stock markets significantly affected the rates of return in Poland, Czech Republic and Hungary. However, propensity of stock markets in Visegrad countries to 
global shocks differed across countries. Polish stock market (in comparison with the stock markets in the Czech Republic and Hungary) reacted much weaker to the situation on the German stock market.

Shocks' transmission mechanism turned out to be very strong. Shocks coming from Germany significantly affected the volatilities on stock markets in Poland, the Czech Republic and Hungary. This mechanism turned out to be asymmetric. Negative shocks had larger impact on the volatilities than the positive ones. After the Lehmann Brothers bankruptcy, the stock markets in Visegrad countries turned out to be less sensitive to global shocks.

\section{Acknowledgements}

The author of the paper gratefully acknowledges the contribution of Prof. Krzysztof Piontek, two anonymous reviewers and the participants of the $3^{\text {rd }}$ WROFIN conference, whose comments have enabled a significant improvement in the earlier version of the paper. The paper was written with the financial support of National Science Centre, Poland, under grant no. 2015/19/D/HS4/03354.

\section{References}

Albuqurque R., Vega C., 2009, Economic news and international stock market co-movement, Review of Finance, vol. 13, no. 3, p. 401-465.

Bieńkowski W., Gawrońska-Nowak B., Grabowski W., 2014, Comovements of Stock Markets in the CEE-3 Countries During the Global Financial Crisis, Eastern European Economics, vol. 32 , no. 5 , p. $32-55$.

Brzeszczyński J., Welfe A., 2007, Are there benefits from trading strategy based on the returns spillovers to the emerging stock markets? Evidence from Poland, Emerging Markets Finance and Trade, vol. 43, no. 4, p. 74-92.

Elliot G., Rothenberg T.J., Stock J.H., 1996, Efficient tests for an autoregressive unit root, Econometrica, vol. 64, no. 4, p. 813-836.

Falagiarda M., Reitz S., 2015, Announcements of ECB Unconventional Programs: Implications for the sovereign spreads of the stressed euro area countries, Journal of International Money and Finance, vol. 53, p. 276-295.

Gilmore C.G., McManus G.M., Tezel A., 2005, Portfolio allocations and the emerging equity markets of Central Europe, Journal of Multinational Financial Management, vol. 15, no. 3, p. 287-300.

Grabowski W., Stawasz E., 2013, Programy skupu aktywów Europejskiego Banku Centralnego w dobie kryzysu zadtużeniowego w strefie euro, Ekonomia Międzynarodowa, vol. 4, p. 5-21.

Grabowski W., Stawasz E., 2017, Sovereign bond spreads in the EMU peripheral countries. The role of the Outright Monetary Transactions, Prague Economic Papers, vol. 26, no. 3, p. 360-373.

Grabowski W., Welfe A., 2016, An Exchange Rate Model with Market Pressures and a Contagion Effect, Emerging Markets Finance and Trade, vol. 52, no. 12, p. 2706-2720.

Horvath R., Petrovski D., 2013, International stock market integration: Central and South Eastern Europe compared, Economic Systems, vol. 37, no. 1, p. 81-91. 
Kilponen J., Laakonen H., Vilmunen J., 2015, Sovereign Risk, European Crisis Resolution Policies and Bond Spreads, International Journal of Central Banking, vol. 11, p. 285-323.

Syllignakis M.N., Kouretas G., 2011, Dynamic Correlation Analysis of Financial Contagion: Evidence from the Central and Eastern European Markets, International Review of Economics and Finance, vol. 20, no. 4, p. 717-732.

Syriopoulos T., 2007, Dynamic linkages between emerging European and developed stock markets: Has the EMU any impact?, International Review of Financial Analysis, vol. 16, p. 41-60.

Winkler A., 2015, The ECB as Lender of Last Resort: Bank versus Governments, Journal of Economics and Statistics, vol. 235, no. 3, p. 329-341. 